\title{
A razão sonhadora
}

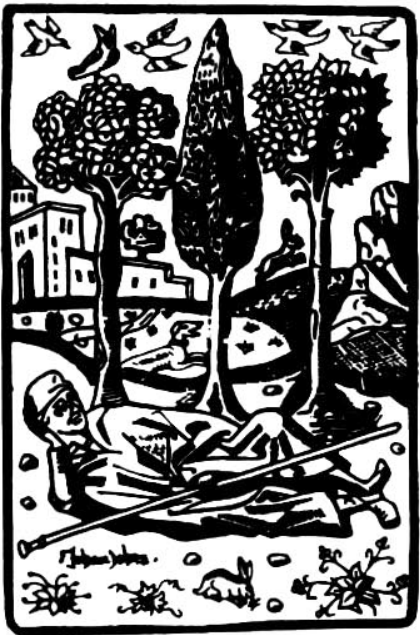

\author{
Roberto Romano
}

Tomemos a filosofia cartesiana, inserindo-a no complexo espiritual envolvente. Isto preocupa os acadêmicos, acostumados às classificações noéticas. Nelas, prende-se o pensamento em rubricas que o desfiguram. Racionalismo, intelectualismo: semelhantes etiquetas afastam a teoria, ideada por Descartes, do caos barroco. Elas divorciam o filosofo de sua própria língua, estilo, cultura. Surge o inefável sistema desprovido de carne, ossos, paixões e vontade. Uma escrita sem imagens, pura “ordem das razões", transparente e incolor. Nesta taxinomia, é ininteligível o nexo entre filosofemas e movimentos particulares da arte, da religião, da política. É impossível acompanhar todos estes prismas. Escasseiam tempo e forças. Como diria Marvell, citado por Auerbach: "Had we but world enough and time..." A partir de alguns textos, indicarei certas convergências entre juízos doutrinários e temas barrocos.

Começo por uma carta. No século XVII, este gênero literário ainda era o veículo essencial para a divulgação do saber, diálogo entre sábios e letrados. Em 15 de abril, ano de 1631, Descartes escreve a Jean-Louis Guez de Balzac (1595-1654): “Durmo aqui dez horas, todas as noites, e sem que preocupação alguma me desperte. Após o sono ter conduzido durante longo tempo meu espírito pelos bosques, jardins, palácios cheios de encanto, onde experimento todos os prazeres imaginados nas fábulas, misturam-se insensivelmente meus devaneios diurnos com os da noite; e quando me percebo desperto, é apenas para que meu contentamento seja mais perfeito, e meus sentidos dele participem; pois não sou tão severo, ao ponto de recusar-lhes alguma coisa que um filosofo possa lhes permitir, sem ofender sua consciência"(1).

Alegria de viver. Pouco notamos, aqui, da ascese estóica. Aliás, o pensador, referindo-se à perfeita alegria, afirma que esta, mesmo para os filósofos do Pórtico, embora sendo uma paixão, pode ser mantida. Alegria na alma e no corpo: "É evidente que a alegria não pode deixar de ser boa, nem a tristeza de ser má (...) se estivéssemos desprovidos de corpo, ouso dizer que não poderíamos nos abandonar demasiado ao amor e à alegria (...) mas os movimentos corporais que os acompanham podem ser nocivos à saúde, quando muito violentos..." Os sentidos saudáveis tambêm causam satisfação, sobretudo "quando o tempo ê mais sereno do que habitualmente"(2). Festa somática e intelectiva.

Estamos longe de um cartesianismo cinza, onde o intelecto puro recolhe-se, inane, em si mesmo, sem corpo. Confunde-se, muito, a separação das substâncias em sua natureza, com ruptura absoluta entre paixões e atos. Mas "embora o agente e o que sofre sejam muito marcados pela diferença, ação e paixão não deixam de ser uma só coisa, com dois nomes"(3). As paixões são o traço marcante do homem: “O que vem à alma pelos sentidos, a toca mais fortemente do que é representado pela razão"(4). O sujeito balança entre os dois extremos, num jogo contínuo de alegria e tristeza. Seu corpo o desafia, opaco para ele e para seus iguais.

Como ultrapassar essa cortina espessa de fumaça? Lendo o rosto, os gestos, as múlti-
ROBERTO ROMANO É professor de Filosofia Polftica do

Departamento de Filosofia do Instituto de Ciências Humanas da Unicamp, e autor de

Conservadorismo romântico (Editora Brasiliense - esgotado), Corpo e cristal-Marx romántico (Editora Guanabara) e Lux in tenebris (co-edição Unicamp-Cortez).

As peças de Corneille e de Racine săo citadas na Ediçăo La Plélade. As de Rotrou, na Coleçăo Laplace (Garnier Freres sd). La Rochefoucauld o citado na ereres dos. Classiques Garnier.

\footnotetext{
1 Oeuvres et lettres, Ediçăo Pléiade, p. $940-1$. O texto que segue resume uma palestra pronunciada na PUC/SP, em seu programa de semlótica (agosto de 1989). Suas consideraçes foram de tivadas antes do aute( brasileiro. Festejando a coincidencia brasileiro. Festejando a coincidencia poeta, espero voltar, em outro artigo, sobre o fato onfrico, a poesia, a razâo em nossa terra.

2 Piéiade, artigo 94, p. 739.

3 Pléiade, artigo 1, p. 695.

4 Pléiade, artigo 85, p. 735.
}

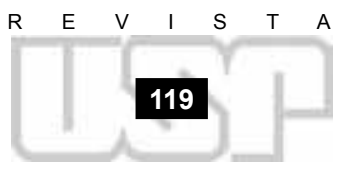


plas máscaras que se apresentam à nossa vista. "Não existe nenhuma paixão que não seja declarada por algum ato dos olhos. $\mathrm{E}$ isto é tão manifesto em algumas paixões, que mesmo os criados mais estúpidos podem notar, pelo olho de seu mestre, que ele está insatisfeito com eles." Cuidado, entretanto: a leitura nunca é direta, imediata: "Embora percebamos facilmente estas ações dos olhos e saibamos o que elas significam, não é fácil descrevê-las". Onde reside a dificuldade? No fato de que as ações visuais englobam muitas mudanças, "ocorridas no movimento e na figura do olho, as quais são tão particulares e minúsculas, que cada uma delas não pode ser percebida separadamente, embora o resultado de sua conjunção seja muito fácil de notar". É árduo recolher, no mesmo instante, o distinto e o unido, conectando síntese e análise. Mas, sem isto, estamos condenados ao engano sobre os outros.

O que se passa com a vista, desdobra-se na imagem exterior, na máscara alheia. "Podemos dizer quase o mesmo das ações faciais que também acompanham as paixões.

Quem foi o correspondente de Descartes? Jean-Louis Guez de Balzac é assim descrito, em "Port-Royal", por Sainte-Beuve: um escritor preso à metáfora em todos os campos das idéias. Tudo só exisłe para the fornecer seu único e favoriło prêmio, a mełáfora
Embora elas sejam maiores que as dos olhos, é difícil distingui-las, e elas são pouco diferentes. Alguns homens fazem a mesma cara quando choram ou riem (...) geralmente, todas as ações, seja do rosto, seja dos olhos, podem ser modificadas pela alma quando, querendo esconder sua paixão, ela imagina fortemente uma contrária; de modo que podemos dela nos servir tanto para dissimular quanto para declará-las"(5). O corpo, na face sobretudo, é espelho que revela e esconde nossa alma. A vigflia oferece oportunidades para se perceber os desígnios da vista. No sono e no sonho, o corpo rapta a consciência, de si mesma e dos outros.

Paixões especulares, homem máscara que revela e se esconde. O Tratado das paixões da alma desenvolve toda uma semiologia das expressões e cores faciais. Engano e desengano. Para captarmos esta temática decididamente barroca em Descartes, precisamos acompanhar a imagem otica e o sonho na sua escrita. Esta, avancemos, inscreve-se conscientemente na prosa e no estilo do tempo.

$\mathrm{O}$ estatuto da imagem, em Descartes, tem sido ignorado pelos estudiosos. Esta falha mostra-se, sobretudo, quando indagamos sobre as figuras retóricas, hipérboles, metáforas, metonímias que povoam sua escrita. Nos últimos tempos a lacuna vem sendo preenchida, com estudos semelhantes aos de P. A. Cahné(6). Infelizmente, a regra ainda é passar rapidamente sobre este aspecto, como o faz Frances Yates: "É pouco provável que Descartes tenha utilizado muito a memória local. Segundo Baillet, na Vie de Monsieur Des-Cartes, ele havia deixado de praticá-la regularmente (...) e a considerava como certa 'memória corporal', 'exterior a nós', que só depende da alma e não aumenta nem diminui. Esta idéia, notavelmente brutal, concorda muito bem com 'o pouco interesse que Descartes manifestava pela imaginação' e por seu funcionamento"(7). Este preconceito pode ser questionado pela simples leitura do filósofo. Por exemplo, o texto citado acima, sobre o complexo jogo entre rosto e olhar. Como entendê-lo, sem acurado estudo sobre a imaginação?

Discurso barroco, a prosa cartesiana sobre as mesmas vicissitudes encontradas na língua culta de seu tempo. Para meditarmos sobre isto, retomemos a carta a Balzac, indicada no início deste trabalho. Quem foi o correspondente do filosofo? Jean-Louis Guez de Balzac é assim descrito, em Port-Royal, por Sainte-Beuve: um escritor preso à metáfora em todos os campos da. idéia ${ }^{(8)}$. Natureza, história, geografia, universo: tudo isto só existe para lhe fornecer seu único e favorito prêmio, a metáfora ${ }^{(9)}$. $\mathrm{O}$ tom pedante o aproxima das Preciosas ridiculas, é verdade, mas ele fez, na prosa, o que Malherbe executou no poema: deu à escrita francesa a "ordem..., a justeza dos acordes, a medida, o poder de uma palavra posta em seu lugar, esta sábia economia do discurso que permite continuar a sua magnificência para sempre"(10).

$\mathrm{Na}$ exposição francesa, ainda apegada ao latim e sem corpo autônomo, ressentindo demasiada inferioridade em face da poesia, Balzac introduziu "um tom, um modo nãopoético, mas oratório, forma de desenvolvimento antes desconhecido neste rigor, e que não foi possível esquecer. Nós o encontramos, quase semelhante, com o pensamento a mais e o gênio suposto, em Jean-Jacques"(11). Críticos de sua época só viram na sua escrita "metáforas impróprias", "hipérboles exorbitantes", “cacozelos", "catacreses" e "outras figuras apavorantes, diz Sainte-Beuve, cujos nomes espantavam os homens ile-

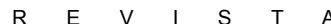


trados, que os tomavam por monstros da África"(12).

Sua dicção define um "desdobramento contínuo da frase, que vai do simples ao figurado, e do figurado ao transfigurado; em toda parte, desde o primeiro ou segundo passo, ocorre a hipérbole com a metáfora"(13). Isto ocasionou a desconfiança de Richelieu, que o viu como um phraseur. O cardeal, decididamente, não gostava de seus enfeites retóricos, mesmo quando elogiava seu estilo: "As concepções de vossas cartas", diz o primeiro ministro ardiloso, "são fortes, e tão longe das imaginações vulgares quanto conformes ao senso comum dos que têm um juízo elevado; a sua dicção é pura, as palavras muito escolhidas, nada tendo de afetado, o sentido claro e distinto (RR: sabemos o quanto esta noção de enárgeia é importante, para Descartes), e os períodos perfeitos, com todos os seus números... seríeis responsável perante Deus se vossa pena fosse deixada ociosa. 'Deveis empregá-la em assuntos mais graves e importantes' "(14). Os poderosos, em especial eles, costumam condenar o jogo estilístico com fim em si mesmo. Como diz certo biógrafo de Richelieu: "Ele era contra a concepção de mundo traduzida no barroco, ele era pela medida e sobriedade clássicas..."(15).

No caso de Balzac, ainda era muito cedo para se efetivar a almejada "atenuação clássica" (klassische Dämpfung), com toda sua carga ideológica de "pureza na dicção, elegância da expressão, nobreza do estilo metafơrico"(16). O cardeal conseguiu fundar um Estado nestes moldes, mas para isto precisou submeter os nobres à corte. O sucesso com os escritores foi mais duvidoso. Balzac, como seus pares aristocráticos, era vaidoso ao máximo. Cultivava o "ego" com alegria, utilizando o Je como Descartes. Definia-se, deste modo, no lado oposto de Pascal, para quem o "eu é odioso". Um amigo de Richelieu, quando interrogado por ele sobre a saúde de Balzac, respondeu-lhe: "Como quereis que ele vá bem? Ele só fala de si mesmo, e a cada vez se descobre; tudo isto o deixa resfriado"'(17). Anedota cruel e fina, na boca de um bom cortesão, já afeito à Raison d'État, contra as veleidades nobres.

Importa, pois, a idéia de prosa, na qual a imagem, segundo Balzac, adquire peso fundamental. $\mathrm{O}$ exagero imagético conduz o escritor até situações deprimentes. Como ao elogiar a Senhorita de Gournay: "Desde o tempo em que sois louvada, a Cristandade mudou dez vezes de face"(18). Tal gosto pela imagem valeu-lhe, ademais, caçoadas, pastiches. Como o de Boileau: "Senhor, o ruído de vossas ações ressuscita os mortos. Desperta os adormecidos desde trinta anos; os condenados a um sono eterno. Ele faz o próprio silêncio falar..."(19).

Pouco importa a zombaria, a vaidade do sujeito. Vale seu remanejamento da escrita, na tentativa - bem-sucedida - de elevá-la. Seus livros, Sócrates cristão e o Príncipe, não o colocam no plano de um sábio religioso, nem o aproximam do gênio maquiavélico. Pelo conteúdo de suas obras, e também por suas Cartas, Balzac não seria lembrado agora. Mas, pela forma, ele mantém um lugar importante na imagética e retórica francesas. No tocante ao culto do "ego", cabe lembrar as observações ásperas de Saint-Cyran sobre Balzac. O último seria "como um homem diante de belo espelho, no qual veria certa mancha em seu rosto, e se contentaria em admirar a beleza do espelho, não apagando a mancha que era preciso ver"(20). Os jansenistas odiavam o "eu", o desdobramento, o teatro, as fantasias barrocas... embora por elas experimentassem fascínio.

Jogo especular, ótico. Sainte-Beuve capta bem o espírito da coisa, ao descrever Balzac, homem barroco, como alguém que era apenas "forma e aparência, uma daquelas pessoas que, mesmo solitárias, passam sua vida em mascarada, não podendo fazer melhor, e considerando que uma face só é bela, quando porta a máscara"(21). Note-se a perfeita continuação entre o juízo sobre a forma de se apresentar, o estilo de Balzac, e o texto das Paixóes da alma, relativo aos olhos e à dissimulação, apontado acima.

Críticas e elogios. A escrita barroca de Balzac tem sido balançada neste pêndulo. Os elogios são feitos na mesma tela, profusamente imagética. Como os de Joubert: "As belas palavras têm forma, som, cor e transparência, que delas fazem o lugar conveniente onde é preciso pôr os belos pensamentos, 'para torná-los visíveis aos homens'. Assim, sua existência é um grande bem, e sua multidão um tesouro. Ora, Balzac é cheio disto, leiam, pois, Balzac'(22).

Finalizemos, com o elogio mais eloqüente sobre Balzac, o manifesto por Descartes. "Qualquer que seja o ânimo com o qual leio estas cartas, seja que as leia para as examinar, ou só para me divertir, delas retiro muita satisfação; e, bem longe de nelas achar algo a ser corrigido, entre tantas coisas belas que ali vejo, tenho dificuldades para dizer quais devem receber mais elogios. A pureza da elocução reina em toda parte 'como o faz a saúde no corpo', a qual nunca é mais perfeita, do que quando menos se faz sentir.

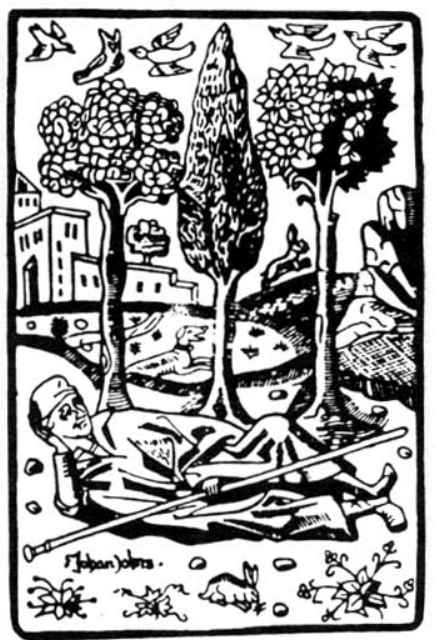

12 Idem, ibidem, p. 547.

13 Idem, ibidem, p. 545.

14 Richelieu, carta a Balzac (4/2/1624). Sainte-Beuve, p. 980.

15 Richelieu, Carl Buckhardt. Paris, Robert Laffont, 1970, v. 1, p. 331.

16 Pour une esthétique de la réception, Hans Robert Jauss. Paris, Gallimard, 1978.

17 Bautru, citado por Sainte-Beuve, p. 542.

18 Citado por Sainte-Beuve, p. 547.

19 Idem, ibidem.

20 Citado por Sainte-Beuve, op. cit., p. 539.

21 Sainte-Beuve, op. cit., p. 983.

22 Citado por Sainte-Beuve, p. 566.

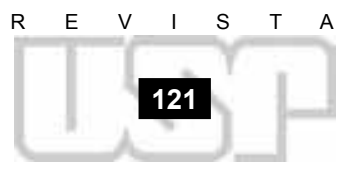




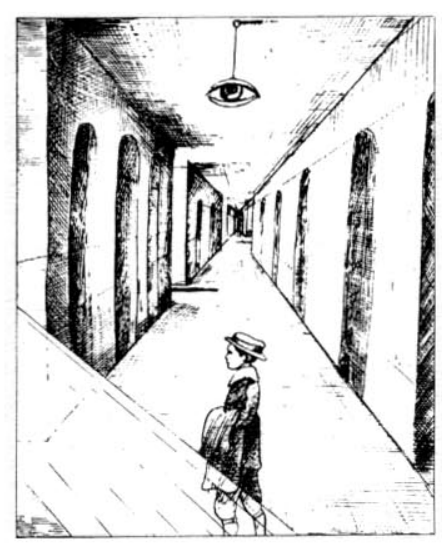

A graça e a polidez nelas reluzem, como a beleza na mulher perfeitamente bela, que não consiste no esplendor de alguma parte em particular, mas num acordo e tempero tão justo de todas as partes juntas, que não deve existir nenhuma que prevaleça sobre as outras, pelo medo de, não sendo guardada a proporção no resto, o composto seja menos perfeito...".

O primeiro símile ótico, a saúde, ressalta a invisibilidade da harmonia, na escrita artística. Luz e sombra, a saúde e a pureza na elocução desafiam o olhar arguto. $O$ segundo comparante, a beleza feminina, opera no visível, agora sublinhando a concatenação decorosa das partes. A carta, gênero literário onde, por excelência, o ausente se apresenta (cf. William Fulwood: "An Epistle or letter, is nothing else but an Oration written, conteining the mynd of the Orator, or wryter, thereby to give to understand to him or them absent, the same that should be declared if they were present' $)^{(23)}$, serve, em Descartes, como exercício de união de face e pano de fundo.

Êmulo de Balzac, Descartes movimenta a técnica barroca da escrita, sponte sua. $\mathrm{O}$ modelo é imitado com leveza e perfeição inventiva. Retornemos à carta onde nosso filósofo relata ao seu correspondente a vida onírica levada em Amsterdam. Ali, são reunidos oxímoros estratégicos: vigília e sono, clara realidade e maravilha noturna, e outros. Com eles, o escritor constrói um movimento contínuo entre o sonhar e o viver alegres. Ausência de cuidados na vigília, encanto no sonho, prazer dos sentidos despertos. Seqüência sem bruscas interrupções, numa curva sinuosa onde não podemos saber qual é o "real", qual o "imaginário".

Lendo a carta, nossa memória automaticamente é conduzida para o grande lugar comum da cultura barroca: a vida ê sonho. Calderon, seguramente: "Yo sueño que stoy aquil de estas prisiones cargado,/ y soñé que en otro estadol más lisonjero me vi./ Que es la vida? Un frenesi./ Que es la vida? Una ilusión,/ una sonbra, una ficción,/ y el mayor bien es pequeño;/ que toda la vida es sueño,/ y los sueños sueños son/".

Mas o quase clichê, hoje, sobretudo após os delírios românticos, não era comum na época cartesiana. O tema onírico invade, naquele tempo, o teatro e a literatura européia. Para ficar apenas em alguns exemplos, entre múltiplos, lembremos que a quase totalidade da Ilusáo cómica de Corneille é um espetáculo noturno. O sonho irrompe em Polyeucte: "Quoi? Vous vous arretêz aux songes d' une ferme (...) Et ce songe rempli de noires visions/ $N$ 'est que le coups d'essai de ses illusions".

Em Athalie, de Racine, o sonho aparece na atmosfera de horror e medo, tal como redescoberta e descrita por Roland Barthes e Erich Auerbach. Como diz o último, nesta peça "aparentemente cristã", não se encontra o menor traço do cristianismo, de sua "tradição antiga e viva", mas só "um capítulo espantoso retirado do recôndito mais tenebroso do Antigo Testamento", onde Athalie "empurra a afirmação enlouquecida de si mesma até a antítese absoluta do cristianismo e atê o absoluto da desumanidade". Nesta peça, diz Auerbach, ressurge, por volta de 1700, "todo o horror de uma luta tribal arcaica"(24). Percebemos, então, a triste angústia evocada pelo sonho: "Un songe (me devrais-je inquieter $d$ ' un songe?)/ Entretien dans mon coeur un chagrin qui le ronge/ Je l' évite partout, partout il me porsuit./C'était pendant l'horreur d' une profonde nuit'.

Ceticismo e medo. Horror pelo desconhecido que irrompe durante a noite. Estes traços podem ser notados nos textos cartesianos, nos momentos em que se referem ao sonho. Mas não só em Calderon, Corneille e Racine o prisma onírico é violento, apaixonado. Rotrou menciona pelo menos doze vezes os sonhos em suas peças. A passagem mais conhecida é a visão de Valeria, em Saint-Genest: "Le premier des Césars apprit bien que les songes/ Ne sont pas toujours des faux et toujours des mensonges". Ou ainda o espetáculo horripilante do sonho vivido por Theodora, em Venceslas. A mulher vê seu irmão sendo despedaçado, antes da decapitação: “Du coup $d$ une main $j$ ' ai vu voler sa tête;/ Et, $m^{\prime}$ '́criant d' un ton qui t'aurait fait horreurl $j$ 'ai dissipé mon songe, et non pas ma terreur"(25).

Toda essa atmosfera pestilenta, vivida no plano do cadafalso, castrum doloris, une sonho, pesadelo, olhar. Retomando Calderon: 'Estas que fueron pompa y alegrial despertando al albor de la mañana,/ a la tarde serán lástima vana,/ durmiendo em brazos de la noche fria..." O sonho da vida passa, e pode trazer o inferno da realidade: "Mira que te as de morirl Mira que no sabes quandd Mira que te mira Dios/ Mira que te esta mirando"'(26).

O sonho barroco, como ocorre em quase todas as figuras desta forma cultural, reduplica a ilusão na realidade, e vice-versa. Forestier indica "o estreito parentesco de dois motivos, magnificamente ilustrados na Espanha por Calderon: o 'mundo é teatro', a 'vi- 
da é sonho'" (op. cit. p. 224). Em Sosie, de Rotrou, por exemplo, dá-se o desdobramento especular da personalidade humana, ampliada para o "cosmos". "Quelque savant démon, en la Magie expert/ Fait qu'ainssi tout se change, et se double, et se perd' '. Esta noção de mutabilidade, inimiga de toda ciência, para Descartes, tamberm evoca o "savant démon", o gênio malicioso que continua o trabalho da dúvida, no sensível, trazida especialmente pelo sonho.

O fato onírico entra, em Descartes, no mesmo terreno da muito barroca temática da Vanitas. Basta retomar o motivo no Discurso do método (1637): "E olhando com um olhar de filósofo as diversas ações e empresas de todos os homens, não há quase nenhuma que não me pareça vã e inútil..." Para conseguir alguma certeza, é preciso cautela máxima: “Como um homem que segue só e nas trevas, resolvi andar tão lentamente, usando tamanha circunspecção em todas as coisas, que, se avançava pouco, eu me guardava de cair". E, neste passo, segue Descartes, antecessor de Rousseau, passeando solitário e sonhando, no relato de sua história, ou de sua "fábula", temendo sempre enganar-se, com a possibilidade de ver "ouro e diamantes" onde, na verdade, só existem "cobre e vidro"...

O sonho definiu as etapas do pensamento cartesiano, da juventude à maturidade. No primeiro momento, ele traz a marca da distância entre o sujeito e ele mesmo. No segundo, trata-se de um campo de prova, no interior do "ego", que deve ser conquistado, se quisermos atingir a plena autonomia. Expliquemo-nos ${ }^{(27)}$.

Nas Cogitationes privatae, o jovem Descartes - tinha ele 23 anos - relata três sonhos, vindos “do alto", de Deus. No primeiro, reina certa angústia. O sonhador acredita ver fantasmas, caminha pelas ruas com o lado esquerdo caído. Um vento forte o arrasta até o colégio onde procura abrigo. Dali, tenta atingir a igreja. Antes de nela penetrar, alguém o cumprimenta polidamente, dizendo que o senhor X deseja dar-lhe um melão. É cercado por pessoas que permanecem em pé, sem dificuldades, ele mal se sustenta. Desperta, "com uma dor efetiva, que o faz temer ter sido o sonho a operação de um mauvais génie cujo desejo era seduzi-lo". Volta-se para o lado direito, rezando, pedindo a Deus "garantias contra os maus efeitos deste sonho, para ser preservado de todas as infelicidades que poderiam ameaçá-lo em punição de seus pecados..." Insone, Descartes reflete sobre os bens e os males mundanos.

$\mathrm{Na}$ mesma noite, segue-se o segundo sonho. Pensa ouvir um barulho espantoso, o toma por um trovão. Com medo, desperta e vê seu quarto invadido por fagulhas. Abrindo e fechando os olhos, observa a "qualidade das espécies (centelhas) que lhe foram apresentadas". Acredita poder dar razões "naturais" para tudo o que vê (ele possui olhos cintilantes, enxerga bem à noite). Dorme, acalmado.

No terceiro sonho, dentro da mesma noite, não sente angústia alguma. Enxerga dois livros sobre sua mesa. Desconhece sua origem. Trata-se de um dicionário e de uma antologia poética. Abre a segunda e lê os versos de Ausonio: "Quod vitae sectabor iter". No mesmo instante, um desconhecido lhe apresenta, com elogios, um poema começando por "Est et non" (outro poema de Ausonio). Descartes deseja mostrar o trecho da antologia, não o encontra no volume que, no entanto, ele conhece bem. Nota nele algumas gravuras. Estas o advertem que se trata de uma outra edição. Somem livros e o desconhecido; o filosofo não desperta.

Sempre dormindo, ele interpreta o sonho: "O dicionário significaria as ciências reunidas; a antologia, chamada Corpus poetarum, marcaria mais distintamente a filosofia que precisava escolher ("Quod vitae sectabor iter"...) e que traria o conselho de um sábio, ou mesmo, da Teologia Moral”.

Assim, duvidando se era sonho seu, ou meditação, Descartes despertou, continuando, com os olhos abertos, a exegese do sonho. "Pelos poetas recolhidos na antologia, ele entendeu a Revelação e o Entusiasmo, quando ele não desesperava de ser favorecido. Pelo verso 'Est et non', o Sim e Não de Pitágoras, ele compreendeu a falsidade e a verdade nas ciências profanas (...) Acreditou que era o Espírito da Verdade, abrindo-lhe os tesouros das ciências." E as gravuras? Foram devidas à visita de um pintor italiano... O melão significaria o encanto do solitário, mas apresentado de forma puramente humana.

Gérard Simon, a quem sigo nestas passagens, assim comenta os traços oníricos: neles, e nas interpretações do próprio Descartes, temos ainda um modo de ver renascentista. O sonho merece análise, possui um "sentido", premonitório ou de advertência. Sua origem é exterior a quem sonha. Descartes, como vimos, o atribui a Deus, opondose ao Diabo (o mauvais génie, malus Spiritus). O sonho liga, quase naturalmente, cêu e terra. Descartes diz-se pleno de entusiasmo (cum plenus forem enthousiasmo). Este

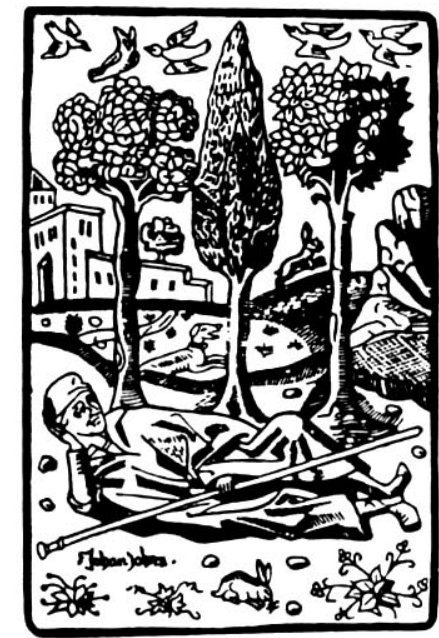

23 The Enimie of Idlenesse (1568), citado por Crane, W. Wit and Rhetoric in the Renaissance. Gloucester. Mass, Peter Smith, 964, p. 77.

24 Citado por Jauss, H. R. obra mencionada, pp. 220-1.

25 Para estes comentários, sigo Fores tier, G. "Le réve littéraire du barroque au classicisme", in Róvue des Sciences Humaines, 211, 1988-3, p. 213 e segs.

26 Citado por Santiago Sebastian: Con trarreforma y Barroco. Madrid, Alianza, 1981, p. 123.

27 A partir deste passo, sigo as análises de Simon, G. "Descartes, le revve et la philosophie", in Révue des Sciences Humaines, número citado, página 133 e segs.

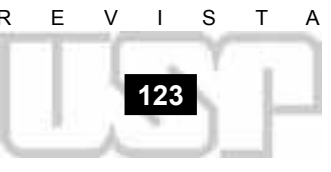


sentimento é creditado por ele, no mesmo texto, ao poeta, para desvelar verdades profundas.

Assim, "podemos nos espantar por encontrarmos mais pensamentos fundamentais nos poetas do que nos filósofos. Há uma razão nisto: os poetas escrevem sob entusiasmo e força da imaginação, pois há no homem germes da ciência, como num sflex, que o filósofo traz à luz pela razão, e que o poeta desvela pela imaginação - eles brilham muito mais"(28).

As metáforas poéticas são definidas, segundo Simon, por intuições analógicas, que conduzem o pensar ao essencial. Descartes guia-se, nesta hora, por elas, identificando em seu sonho, entre os demais símiles, a luz e o conhecimento, o sopro e o espírito. "Como a imaginação serve-se de figuras para conceber os corpos", diz o próprio Descartes, "também a inteligência, para figurar as coisas espirituais, serve-se de certos corpos sensíveis, como o vento, a luz. Donde segue-se que, filosofando de modo mais elevado, poderemos, pelo conhecimento, conduzir o espírito ate os mais altos cumes". Pensamento baseado nas similitudes, se quisermos empregar o léxico de Michel Foucault, no capítulo segundo de As palavras e as coisas. O mundo é um cosmos povoado de signos, imagens que remetem-se umas às outras, interminavelmente.

"O jovem Descartes, enuncia Simon, ao caminhar mascarado no grande teatro do mundo, e viver solitário uma noite turvada pela angústia e pela esperança, em seu quarto na Alemanha, não está muito longe de Lady Macbeth, a qual, quinze anos antes, em Londres, esfregava as mãos sujas de sangue numa cena de sonambulismo. Sem dúvida, um é real, e outra, fictícia. Mas as duas personagens se pensam no interior da mesma cultura, em que os sonhos queriam dizer algo."

Mas Michel Foucault não é o único, longe disto, que nos pode dizer algo sobre este modo de conceitualizar. E, também, é preciso cautela com os limites epistêmicos. Claro, na Renascença, os símiles cumprem este papel de incorporar os significados analógicos. Mas, mesmo na vida cristã, mais antiga e envolvente - como interdito ou incentivo - no Medievo e no Renascimento, a imagem efetiva este mister ${ }^{(29)}$. Parece importante guardar, no pensamento do jovem Descartes, a junção entre poesia e racionalidade. Nele opera, no meu entender, o critério da "significância", estudado com muito apuro por Rosemund Tuve.

No pensamento dessa última autora, "tanto na crítica quanto na teoria retórica, é um lugar-comum aceito que o abstrato e o intangível requerem o auxílio 'das imagens terrestres' (Peacham, da metáfora, p. 12). A necessidade da metáfora ê notada freqüentemente como sua graça e beleza. Muito desta beleza, no entanto, consiste em sua habilidade para transcender as limitaçōes da língua (...) Nem sempre é lembrado que, com a metáfora e tropos conexos, é inescapável a relação com o mundo supra-sensível. Isto é simples, mas profundo"'(30).

Sem demasiadas pressões sobre o campo estudado, poder-se-ia dizer da imagética cartesiana, neste período juvenil, o mesmo que é dito sobre Dante: o poeta "tem uma imaginação 'visual'. Visual, num sentido diferente à do pintor moderno da natureza morta: é visual no sentido de que ele viveu numa idade durante a qual os homens viam visões. Era um hábito psicológico, cuja arte esquecemos, mas que é tão boa quanto as nossas. Nós só temos 'sonhos', esquecemos que o ver visões (...) foi um dia um gênero de sonho 'mais significativo', mais interessante, e mais disciplinado. Damos como certo que os nossos sonhos vêm daqui, da terra: possivelmente a sua qualidade sofre por isto"'(31).

Em Descartes sucedem-se as duas visões do homem e do Além. A primeira enxerga, 118 , nota 21 .

29 Cf. L'icone du Christ, Chr. Schönborn. Fribourg, Ed. Univer. 1979. Também De Lubac: Exegèse Médié vale. Aubler, Paris, 1964.

30 Ellzabethan and Metaphysical Ima gery. London, Univers. Press, 1947, pp. 155-6.

31 "Dante" (1929), T. S. Eliot, in Select essays. London, Faber and Faber Limited, 1980 (1" ed. 1932), p. 243.

32 Cf. Idées médicales, Docteur Grasset. Paris, Plon, 1910, p. 282. Sobre o assunto, no aspecto da melancolia, ct. The demon of Noontide. Ennul in western literature, R. Kuhn. New Jersey, Princeton, 1976.

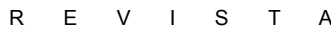
dana. O poeta, neste sentido, com seu entusiasmo, traz para o visível o que não tem corpo, o encarna. Por isto, supera o filósofo, que vai ao invisível pelo fenômeno. Descartes, posteriormente, mas nunca em termos absolutos, rompe com este itinerário do real aos sonhos, e vice-versa.

A ruptura torna-se notável no Discurso do método. À diferença do que ocorria nas Cogitationes privatae, o característico do sonho, agora, é gerar ilusões: “Considerando que todos os mesmos pensamentos, que temos acordados, podem nos vir quando dormimos, 'sem que nenhum seja verdadeiro', resolvi 'fingir' (feindre) que todas as coisas que entraram em meu espírito não eram mais reais do que a ilusão de meus sonhos”. O recurso poético, a ficção, entra agora na própria trama metరdica. Mas, em contrapartida, o sonho adquire o estatuto de pura ilusão. Suas visões já nada significam, na ordem da ciência, da moral, etc. 
Antes, havia um critério para distinguir sonho e realidade: o sonho "verdadeiro" anunciava o real futuro, porque vinha de "Deus". Era este o seu "sentido". Agora, perde-se todo seu valor referencial, presente ou futuro. $O$ lugar e tomado pelo pensamento desperto. Mas, como saberemos se este último também não é um sonho, enquanto a mensagem trazida por ele não for validada por Deus? Por outro lado, como saberemos, diz barrocamente o Discurso do método, que "os pensamentos vindos em sonho são mais falsos do que os outros, se freqüentemente eles não são menos vivos e expressos? Estudem os melhores engenhos, tanto quanto quiserem, não acredito que possam dar nenhuma razão suficiente para extrair esta dúvida, se eles não pressupõem a existência divina". "Mira que te mira Dios/ Mira que te esta mirando..."

Deus não engana. Condição para não "nos" enganarmos é acreditar nas idéias claras e distintas, as únicas que recebem garantia divina. A exigência da chiarezza penetra no âmago do itinerário filosófico interno ao mundo. "Após o conhecimento de Deus e da alma nos ter feito certos desta regra (a de que a certeza só é trazida pelas idéias claras e distintas) é fácil, então, conhecer que os devaneios (rêveries) que imaginamos ao adormecer, não nos devem, de modo algum, fazer duvidar da verdade dos pensamentos que temos, quando despertos". Autoconsciência "clara", o cogito possui uma inteireza que o sono não apresenta: "nossos raciocínios nunca são tão 'evidentes' nem tão inteiros durante o sono, do que durante a vigflia". A etimologia latina de "evidente", aqui, adquire sua conotação ótica plena: só podemos "ver" quando nossos olhos encontram a luz. À noite, tanto os olhos do corpo, quanto os da alma, são vítimas das trevas, do que é "confuso e obscuro", apenas sombrio.

As Meditationes de prima philosophia, 1641, obra mestra do filosofo, caracterizam o sonho mais como uma desregulagem do senso comum. A primeira Meditação compara sonho e delírio insensato, no qual acreditam os que se pensam "reis", "ou imaginam serem bilhas, ou possuir um corpo de vidro". Nenhum destes sintomas é desconhecido pela sabedoria do tempo. Basta lermos a Anatomia da melancolia, de Robert Burton (1621). Mesmo a literatura médica moderna guardou estes elementos: "O irmão de Richelieu, o mais velho, acreditava ser Deus Pai; sua irmã acreditava ter um traseiro de cristal, não queria sentar-se com medo de quebrá-lo, e o tinha cuidadosamente entre suas duas mãos...’(32).

Dormindo, representamos as mesmas coisas que os loucos, quando eles estão despertos. Ou sonhamos coisas mais extravagantes ainda, comenta Simon sobre o espírito cartesiano. Enquanto dormimos, damos fé aos sonhos, tanto quanto às nossas percepções, quando despertos. "Entre as percepções causadas pelo corpo, a maioria depende dos nervos", enuncia o Tratado das paixōes da alma (artigo 21). Mas existem outras, que deles independem, as quais denominamos "imaginações", mas que delas diferem, porque involuntárias. "Tais são as ilusões de nossos sonhos, e tambem os devaneios (rêveries) que temos freqüentemente quando despertos, quando nosso pensamento erra com displicência sem aplicar-se a nada."

Notemos, ao contrário de Frances Yates, o quanto Descartes se preocupa, e muito, com a imaginação. Mas, além disto, para pensar as diversas impressões imaginárias, que nos conduzem ao erro, ele utiliza a linguagem pictórica: "As imagens, que che-

gam ao cérebro pelos nervos, são mais vivas e mais expressas do que as excitadas ali pelos espíritos". "O que me levou a dizer", comenta Descartes: "estas são como a sombra e a pintura das outras. É preciso notar, que ocorre às vezes ser esta pintura tão semelhante à coisa representada, que podemos nos enganar, no relativo às percepções dos objetos exteriores a nós (...) assim, freqüentemente quando dormimos, e mesmo às vezes, quando despertos, imaginamos tão fortemente certas coisas que pensamos vê-las diante de nos" (artigo 26, do mesmo Tratado).

O sonho, pois, não e mais uma intervenção divina, mas efeito da união entre corpo $\mathrm{e}$ alma, uma desregulagem passageira da máquina corporal. Logo, o sonho é desprovido de significação, fora deste plano mecânico. Isto permite distingui-lo da vigília. A forte angústia, que esta perspectiva produz, foi sentida por Descartes, e por ele expressa em páginas dignas do mais delirante surrealismo. "Com efeito, se alguém, quando estou desperto, me surgisse subitamente e desaparecesse igualmente, como o fazem as ima-

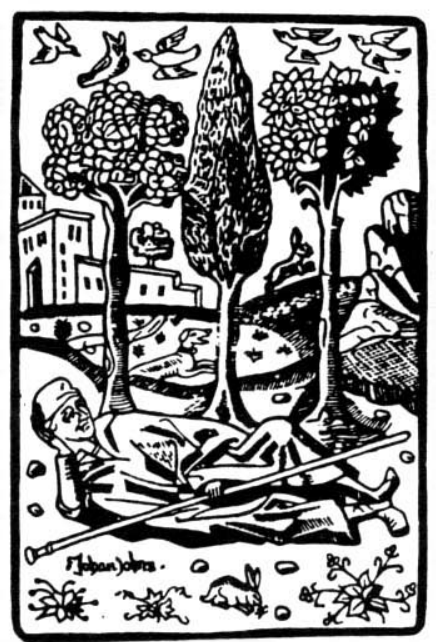

\section{Sem demasiadas pressões sobre o campo estudado,} poder-se-ia dizer da imagética cartesiana, nesse período juvenil, o mesmo que é diło sobre Danłe: o poeła "łem uma imaginação 'visual', no sentido de que viveu num tempo em que os homens viam visões"

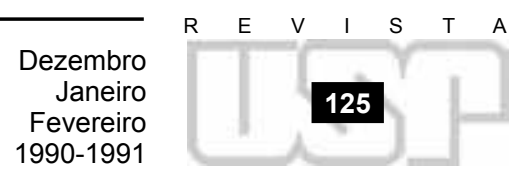




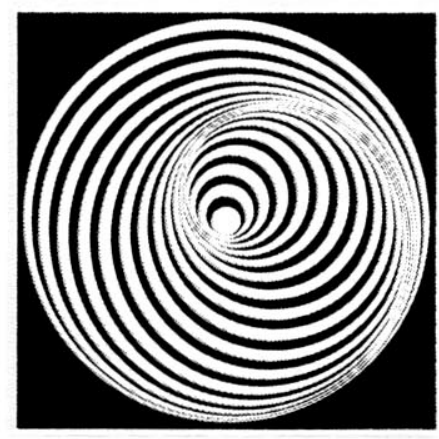

gens que vejo ao dormir, de modo que eu não pudesse notar nem de onde ele vem, nem para onde vai, não seria sem razão que o consideraria um espectro, ou fantasma formado em meu cérebro, e semelhante aos que nele se formam quando durmo, e.não um verdadeiro homem..."

Como reconhecer, nas aparências, a verdade? Como identificar os que estão fora de mim? Algumas regras diminuem a incerteza, não a resolvem: "Quando percebo coisas das quais conheço distintamente o 'lugar' de onde elas vêm, e 'onde' elas estão, e o 'tempo' no qual elas me aparecem, e que, sem 'nenhuma interrupção', posso unir o sentimento que delas tenho, com a seqüência do resto de minha vida, fico inteiramente seguro que as percebo quando vigilante, e não no sono". A vigília dá-nos a "continuidade" das coisas em seu tempo e espaço. Nada mais a separa do sonho. As impressões imediatas calam-se diante disto.

Este é o clima preocupante da Segunda meditação: ela se inicia na plenitude barroca da Vanitas, e do fantástico: “Suponho, pois, que todas as coisas que vejo são falsas; me persuado de que nada existe, de tudo o que minha memória, cheia de mentiras (mensonges, o significante é sempre refletido por songes) me representa; penso não ter nenhum sentido; acredito que o corpo, a figura, a extensão, o movimento e o lugar nada mais constituem do que ficções de meu espírito. $\mathrm{O}$ que poderá ser considerado verdadeiro? Talvez nada mais, a não ser que nada no mundo é certo".

Não ê um estranho à cultura barroca quem diz: “Considerei a mim mesmo, primeiramente, como tendo um rosto, mãos, braços, e toda esta máquina composta de ossos e carne, tal como ela aparece num cadáver..." O juízo surge como o único corretivo para a incerteza universal: "Se por acaso eu olhasse da janela homens que passam pela rua, à vista dos quais eu não deixo de dizer que vejo homens (...) entretanto, o que vejo desta janela, a não ser chapéus e capotes, que podem cobrir espectros ou homens fictícios (feints) que se movem apenas por molas? Mas eu julgo que são verdadeiros homens, e compreendo, só pelo poder de julgar que reside em meu espírito, o que eu acreditava ver com meus olhos".

Descartes nega que as coisas sejam tais como se apresentam de modo imediato. Elas não são verdes, ou amarelas, em si mesmas, secas ou úmidas, frias ou quentes; embora produzam impressões qualitativamente diversas, elas só diferem por propriedades espaciais, forma, movimento de suas partes ${ }^{(33)}$. Surge, então, o verdadeiro problema: se o mundo só nos envia "sinais", e as coisas não são como se mostram, se nada pode ser discernido nelas, a não ser um pouco de movimento que Deus mantém no ser por uma criação "contínua", a vida da consciência desperta não é menos prisioneira das aparências do que a da mente adormecida. Não apenas ela não vê o que acredita ver, mas o que nela se passa não tem mais consistência intrínseca do que um sonho bem ligado.

"A consciência", arremata Simon, "só desperta verdadeiramente ao renunciar a si mesma, à sua imediatez, para se tornar um pensamento que pensa a si mesmo, uma reflexão. Mas esta consciência vigilante ê pura razão", sem objetos exteriores a si mesma. Só Deus pode garantir que os signos por ela recebidos se relacionam com as coisas existentes em si mesmas. Só o autor de tudo garante o espetáculo interno da consciência. Logo, esta última, como no sonho anterior, no jovem Descartes, retira seu valor de "cima", do divino.

Aqui, precisamos retomar o trecho do Tratado das paixões da alma, sobre o relacionamento dissimulado entre a face e o olhar. Vimos que é importante o traço "contínuo", e o "desdobramento" em todas as operações espirituais. Esta é uma das mais fortes características do barroco: a coisa dentro da coisa, o ato dentro do ato, o teatro dentro do teatro, o sonho dentro do sonho, o pensamento dentro do pensamento, a pintura dentro da pintura. Neste jogo especular entre a primeira impressão e as formas embutidas - mas insuspeitadas - nos delineamentos superficiais, na passagem meditada da aparência à essência, dos reflexos para os reflexos, se compraz a práxis no século XVII. Desejo de tudo ver, tudo escondendo. Este traço passa pela ótica, religião, política, do tempo e da cultura barroca.

Jur jis Baltrußaitis tem investigado os vários aspectos da ilusão ótica, na pintura, no espelho, no teatro, no mito. Discute, sobretudo, o jogo dos reflexos na anamorfose, conectada com a representação de poder, no século XVII. Entre muitos quadros, analisa o Vexierbild do pintor Schön, "formado por quatro registros trapezoidais onde riscas zebradas se prolongam em paisagens com figurinhas vivas. Cidades e colinas, personagens e animais, mergulham numa torrente de traços entrecruzados, que nada explica 'à primeira vista'. Mas, colocando o olho de lado, bem perto da gravura, vemos surgir 
quatro cabeças superpostas no interior dos quadros retilíneos. A perspectiva torna invisíveis as imagens aparentes e, no mesmo golpe, faz aparecer os contornos escondidos. Os personagens são perfeitamente identificáveis: Carlos V, Ferdinando I, o papa Clemente VII, Francisco I"'.

Este procedimento adquiriu uma importância cada vez maior na pintura, e na representação filosófica do mundo, à medida que passou o século XVII. Na Vexierbild de Schön se imbricam técnica ótica, religião e poder. Todos estes elementos se desdobram, numa continuidade insuspeitada à primeira vista. A falta inicial de sentido é corrigida pelo olhar vigilante, na sua busca de figuras claras e distintas.

"O grande teórico da anamorfose foi, no século XVII, Jean-François Niceron que pertencia à ordem dos Mínimos. Sua Perspectiva curiosa (...) é uma tentativa de visualização da dúvida cartesiana, fundada sobre a experiência de que nossos sentidos nos enganam às vezes. A anamorfose transcreve no campo artístico uma noção filosófica essencial, nascida do progresso científico, e duplica a ciência, acompanhando cada etapa de seu desenvolvimento (...) mas a anamorfose ultrapassa, e muito, Descartes. Sob seu rigor clássico, ela trabalha a consciência. Ela jâ faz presente o arrepio barroco"'(34).

Qual o fito da anamorfose? "Revelar e dissimular ao mesmo tempo, mostrar pela metade." Uma das mais conhecidas anamorfoses é o quadro Os embaixadores, de Holbein (1533). Ainda renascentista, esta obra já anuncia aspectos modernos. Seu tema é o "da morte escondida que marca o fim da morte cristã". Se deixarmos a caveira no centro do quadro, o que deu-lhe imensa celebridade, veremos um último detalhe: "um minúsculo crucifixo de prata, posto entre o enquadramento barroco da obra e a cortina de seda verde que ocupa seu fundo. Ainda uma dissimulação, visível com dificuldade, no ângulo superior da pintura. Pode-se ver um aviso do céu, uma espécie de janela entreaberta para o Além, completando o sentido da anamorfose (...) Holbein, que nos seus 24 anos tinha murado o Cristo, agora o escamoteia. Faz o seu cadáver desaparecer (...) $O s$ embaixadores é, na realidade, o primeiro surgir da consciência moderna sobre a morte. Não deixando de se estender, até nós, a mancha cega do Nada"'(35).

É possível, pois, desconfiar por que um cartesiano, polidor de lentes e afeito à ótica, Espinosa, escreveu um inacabado texto sobre a Emendatio, a "correção" do intelecto. Se quisermos conhecer algo, cabe-nos corrigir a vista. Comentando a Vexierbild de Schön, Baltrusaitis(36) diz que, nela, a "visão toma lugar numa paisagem ondulante, marcada pelo poder soberano que ela própria marca" (p. 15). Voltarei a este ponto, o poder simulado e dissimulado pelo artifício ótico. Antes, vejamos o que diz o autor, das relações entre Descartes e a anamorfose.

Para o filósofo do século XVII, “como para Platão, existe uma diferença entre a realidade e seu juízo. Mas não se trata apenas das obras de arte. As obras da vida, elas próprias, são fantasmas". O já citado Niceron levou à execução as teses cartesianas sobre a divergência entre o verdadeiro sensível, e o real. Inventou um procedimento que fazia aparecer temas escondidos num quadro, que utiliza uma fórmula da Dioptrica, publicada um ano antes. Trata-se de pintar uma figura muito pequena e invertida, sobre um anel ou medalha, representada numa pintura de modo a ficar imperceptível. "Mas, diz Niceron, colocando a luneta oposta diretamente a este pequeno objeto, ela aumentaria de tal modo a sua aparência, que se veria as menores partes 'muito distintamente', o resto da pintura não mais aparecendo, o que ocorreria com maior sucesso, se nos servíssemos do vidro ou cristal da forma e figura prescritas pelo senhor des Cartes, nos Discursos 8, 9 e 10 de sua Dioptrica"'(37).

Do procedimento técnico ao método, a busca da clareza e distinção estabelece um itinerário. Mesmo nos instantes especulativos mais elevados, o campo ótico penetra a escrita cartesiana. Seu movimento é ao mesmo tempo "poético" e ótico. Referindo-se à difícil determinação do estatuto próprio do pensamento, seus lados intuitivo e dedutivo, J. M. Beyssade diz que, na filosofia cartesiana, o ato de pensar não pode ser nomeado, sem mais, como "intuição", pois não comporta apenas dois termos (as intuições de relação) mas um termo e um movimento; nem uma "dedução" uma vez que "ele implica, pelo menos enquanto limite, uma intuição, continuada ou adquirida. Trata-se de uma intuição na qual um movimento substituiria o segundo termo, ao invés de um movimento dedutivo que manteria presente seu primeiro momento intuitivo. Uma análise real e não-lógica encontra, como elemento constitutivo do pensar, o ritmo trocaico: uma atenção que se alonga num termo, se abrevia para passar ao segundo, depois recomeça".

O ritmo poético une-se à ótica: existem conjuntos que os olhos colhem, desde o ini-

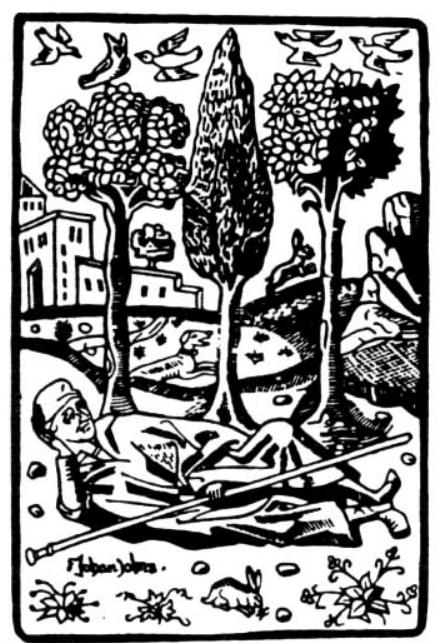

33 Estou seguindo muito de perto, nestes trechos todos, o texto citado de Simon. O leitor poderá constatar onde dele me aproximo, e onde dele me afasto.

34 Cf. Les ambassadeurs, J. L. Ferrier. Paris, Gonthier, 1977.

35 Idem, ibidem.

36 e 37 Anamorphose. Paris, Flammarion, 1984, pp. 15 e 67-8. 
cio, em sua unidade, porque compostos de elementos pouco numerosos e simples individualmente: uma letra ou número. Mas existem outros conjuntos que deciframos de início, por um "movimento" do olhar, como "numa galeria de pintura, onde o experimenta o espectador cujo olho se detém nos detalhes, segue uma curva caprichosa ou regrada, retorna e, por vezes, no termo de uma apreensão sucessiva, ou graças a um deslocamento do corpo inteiro para encontrar o melhor ponto de vista, colhe o todo num s6 golpe do olhar. Mas, na maior parte do tempo, quando se trata do quadro, sempre quando se trata de ronde bosse (obra em relevo, que se destaca do fundo, e ao redor da qual pode girar), não há ponto de onde tudo pode ser visto ao mesmo tempo e 'com distinção': a escultura pede um deslocamento ao seu redor, e a passagem pelos perfis privilegiados, que não poderia nunca ser substituída pelo artifício ótico dos espelhos, o quadro pede um movimento de aproximação e distância, o desdobramento, até a distinção dos detalhes que só emergem obscurecendo a visão do resto. $\mathrm{O}$ recuo faz vibrar, indistintamente, estes fundos a que renunciamos a explicar para colher o conjunto. Assim, é ao movimento dos olhos que se oferece um espetáculo complexo, e nunca uma vista instantânea"(38).

Finalizando seu belo livro sobre as imagens no pensamento moderno, F. Dagognet diz que, em Descartes, "basta esquecer as advertências e as conclusões sobre os erros sensoriais, ou nossas ilusões óticas, para que respiremos uma filosofia nova e moderna, a da câmara obscura tão bem analisada na Dioptrica, que nos mostra a imagem ao mesmo tempo representativa do objeto, mas dele diferente. Descartes atribui muito a estes jogos; ele só os desvaloriza no final, com argumentos conhecidos: sua evanescência e ilusionismo". Mais adiante, diz Dagognet: "Descartes conheceu o poder dos artifícios, o jogo das ilusões (...) Seus textos mais clássicos estão plenos de prodígios e de experiências quase barrocas (RR: por que não barrocas?); assim, lemos nos Principia (artigo 187 do Livro IV) sobre 'os efeitos raros e maravilhosos, como o de sangrar as feridas do morto, quando o assassino dele se aproxima, agitar a imaginação dos que dormem, ou mesmo, dos que estão despertos, e lhes dar pensamentos que os advertem sobre as coisas longe deles... os maus desígnios de um assassino' (...) Mas", arremata Dagognet, "ao invés da Fantasmagoria permitir a concepção de um real estranho, suscetível de anamorfoses, ela serve, pelo contrário, para transformar o mundo num imenso sonho; tudo então se evapora e se irrealiza (a terra movente e a areia) e isto em proveito do cogito e de Deus (rocha e argila)"(39).

Contra a estranheza entre o caminho cartesiano e as anamorfoses, os trabalhos citados de BaltruSaitis são eloqüentes. Mas a que se refere aquele medo, constante preocupação com os assassinatos distantes, e os sinais que permitem ler seus desígnios maleficos? Da ótica passamos, aqui, à reflexão sobre o poder, contida na anamorfose. Esconder e se esconder, revelando. Isto é algo bem conhecido de Descartes, desde a juventude. Em 1618, ele deixou a França, indo para a Holanda, onde se alistou no exército de Mauricio de Nassau. Em 1619, já está na Alemanha, quando toma conhecimento de uma revolta política na Boêmia, uma guerra entre católicos e protestantes sobre ela. Deslocase para as margens do Danúbio, num quartel de inverno. Justamente o lugar onde teve

É possível, pois, desconfiar por que um cartesiano, polidor de lentes e afeito à ótica, Espinosa, escreveu um acabado texto sobre a "Emendatio", a "correção" do infelecto. Se quisermos conhecer algo, cabe-nos corrigir a vista os três sonhos mencionados. Aí, entra em contato com pessoas que ouviram falar dos rosacruzes, os quais prometeriam uma nova sabedoria, nova ciência ${ }^{(40)}$. Tentou relacionar-se, em vão, com os irmãos da seita. Estes eram acusados de se tornarem invisíveis, constituindo ameaça para os poderes estabelecidos, na Igreja e nos Estados.

Escutemos o senhor Baillet, primeiro biógrafo do pensador: "Quando Descartes chegou em Paris, os negócios do infortunado Conde Palatino, eleito Rei da Boêmia, as expedições de Mansfeldt, e a transferência do Eleitorado, do Conde Palatino para o Duque da Bavária, feita em Ratisbona, em 15 de fevereiro, forneciam matéria para a discussão pública. Descartes podia satisfazer a curiosidade de seus amigos neste ponto, mas em troca eles lhe deram novidades que o angustiaram, tão incrível elas pareciam. Tratava-se de falar, desde poucos dias em $\mathrm{Pa}$ ris, dos irmãos rosacruzes, a quem ele procurou em vão na Alemanha, no inverno de 1619, e corria o rumor de que Descartes estava unido a esta companhia.

Ele estava surpreso com estas notícias... Em Paris, os rosacruzes eram chamados "os
$\mathrm{R}$

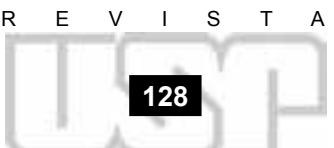

Dezembro

Janeiro

Fevereiro

1990-1991 
invisíveis" (...) pois não tendo como comunicar-se com o povo, só o fariam pelo pensamento, unido à vontade, isto $\varepsilon$, de um modo imperceptível aos sentidos. Havia muita chance de que Descartes, chegando a Paris junto com os rosacruzes, teria sua reputação confundida com a deles, se ele tivesse se escondido, ou vivido solitariamente, como costumava fazer em suas viagens. Ele fez-se visível para todo mundo, sobretudo para seus amigos, que não precisaram de outro argumento para provar que ele não pertencia aos rosacruzes....(41).

Na mesma Paris, séculos depois, teremos um conto policial, "A carta roubada", em que se utiliza o mesmo ardil para esconder o alvo: torná-lo visível... em demasia. Anos após a aventura narrada por Baillet, em 1644, Descartes se estabelece em Leiden, às ordens da Princesa Elisabeth do Palatinado, filha mais velha do triste Eleitor Frederico, que havia morrido em 1632. Frances Yates pergunta-se a razão do interesse cartesiano pelos negócios palatinos, e levanta algumas interrogações sobre a viagem alemã, quando o filósofo teria procurado os rosacruzes, "em busca de sabedoria". Qualquer que seja a resposta, se Descartes uniu-se às movimentações políticas escondidas, ou se os fatos passaram por ele apenas, o certo, o que define sua perspectiva barroca, é o tema da invisibilidade visível.

Este já é o assunto de uma outra carta, escrita por Descartes a Balzac, em 5 de maio de 1631 (um ano antes da morte do Eleitor Palatino...). Balzac lhe havia anunciado o desejo de se recolher, escapando da vida servil na corte. Tamberm lhe anuncia o anseio de visitar a Holanda, onde o filósofo se achava. Após várias considerações sobre os inconvenientes dos refúgios possíveis, Descartes escreve a Balzac: "Na grande cidade onde estou, não existindo nenhum homem, exceto eu, que não comercie, cada um é tão atento ao seu lucro, que eu poderia permanecer toda a minha vida SEM SER VISTO POR NINGUÉM. Vou passear todos os dias entre a confusão de um grande povo, com tanta liberdade e repouso quanto vós teríeis em vossas aléias, e NÄO CONSIDERO DE OUTRO MODO OS HOMENS QUE VEJO AQUI, DO QUE ÁRVORES QUE SE ENCONTRAM EM VOSSAS FLORESTAS, ou animais que ali passam. O próprio barulho que eles fazem, não INTERROMPEM MEUS DEVANEIOS (rêveries), tanto quanto não o faria um riacho (...) Em qual outro país poder-se-ia escolher para habitar, no resto do mundo, se não fosse este? Aqui, todas as comodidades da vida, e todas as curiosidades que podem ser desejadas, são fáceis de encontrar. Em que outro país gozarfamos uma liberdade tão inteira, e dormiŕamos com menos inquietude? Onde haveria estes exércitos para nos guardar? E OS ENVENENAMENTOS, AS TRAIÇŌES, AS CALÚNIAS seriam menos conhecidos?".

Se "A carta roubada" nos veio à memória, agora é o Homem da multidão(41). Holanda, país livre onde passeamos invisíveis, no interior mesmo da visibilidade. Elogio que será partilhado por toda a filosofia européia, de Espinosa até Diderot. Descartes termina sua carta a Balzac, escrevendo: "Eu vos espero com uma pequena recolha de devaneios (rêveries) que não vos serão desagradáveis".

$\mathrm{Na}$ época, Balzac dizia aos seus amigos que desejava permanecer, doravante, cada vez mais escondido. Por exemplo, na carta a Dom André de Saint-Denys: "Aviso que, enquanto eu estiver entre Loire e Loiret, pretendo estar 'incógnito' (palavra recente no léxico, lembra Sainte-Beuve). Não me chamarei, por favor, neste país, nem Balzac, nem Narciso, nem Aminto; não tomarei nem receberei outro nome de guerra que possa me descobrir. Meu desejo não é dar reputação ao meu retiro: seria querer ser obscuro com brilho... É preciso que, estando entre vós, eu seja um segredo para vós e para mim, um enigma para todos os outros"(42).

Em Paris, dominada pela desconfiança, envenenamentos, traições, calúnias, o melhor foi fazer-se invisível. Em Amsterdam, pelo contrário, era possível fazer-se invisível, sem atingir o "obscuro com brilho". O sonho maravilhoso, na carta citada acima (página 1), continua numa outra (5/5/1631). Na primeira, o sonho encantado se passa entre os "bosques, jardins". Na segunda, o mesmo sonho ocorre entre homens-árvores, que não interrompem os devaneios do filósofo. Sonhos próximos ao pesadelo, é verdade. Homens surgem na janela, sem que saibamos se representam puras máquinas, manequins, máscaras (espiōes são outra coisa?) ou homens-plantas: tudo isto, confessemos, angustia.

Comentando o ideal de transparência e de mecanismo absolutos, como posto na filosofia cartesiana, Denise Leduc-Fayette enuncia: "Esta fascinação não vem de agora, e seria preciso ser psicanalista para colocar às claras as suas motivações profundas. Os esquizofrênicos se perguntam se eles próprios, e tudo o que os envolve, são algo mais

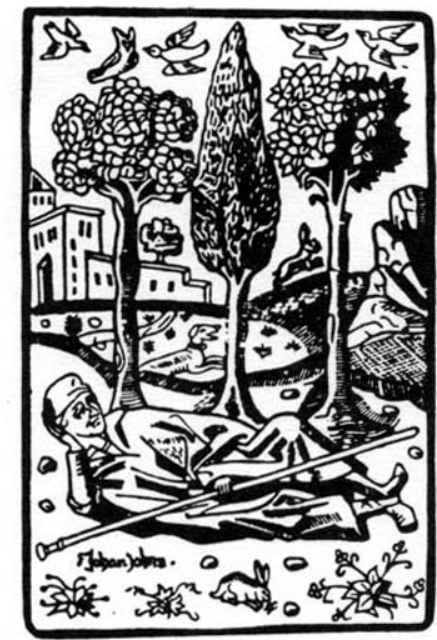

$38 \mathrm{Cf}$. La philosophie premiere de Descartes, J. M. Beyssade. Paris, Flammarion, 1979, pp. 148-9. O nexo entre $\circ$ pensamento cartesiano e anamorfose foi-me indicado, na primeira vez, pela Profe Ligia Fraga da Silveira (Unesp-Marllia Depto de Filoso fia) a quem agradeco. Aguardo seus ila) a quem agradeço. Aguardo seus trabalhos sobre o assunto, para citá-la mais definidamente.

39 Philosophie de l'image, F. Dagognet. Paris, Vrin, 1984, pp. 225-30. Cf. também, sobre a problemática da anamorfose. Maneirismo: o mundo anamo como labirinto, G. R. Hocke, SP,
Perspectiva, Col. Debates, p. 203 e segs.

$40 \mathrm{Cf}$. The rosacrucian enlightenment, F. Yates. Bouldes, Shambala, 1972, p. 116.

41 L. Santaella, em seu estudo sobre Poe ("O que em mim sonhou está pensando") trava uma reflexăo idêntica à de J. M. Beyssade já citada. Re firo-me à "crítica do raciocínio puramente matemático, isto ê, da deduçăo pura" e à "feliz confluencia das habilidades matemáticas com as postilidades matemáticas com as poéticas. Todo o estudo de Santaella pode servir-nos como comparante, com muito proveito, tanto para as imagens, quanto para a poesia. Mas, sobretudo, para o sonho. Cf., também, a questão da anamortose, em Poe, no instigante livro de Claude Rabant, Delire et theorie. Paris, Aubier, 1978, 75. O autor cita justamier,  taella $\theta$ editado em Săo Paulo (Cultrix, 1984), p. 160.

42 Citado por Sainte-Beuve. 


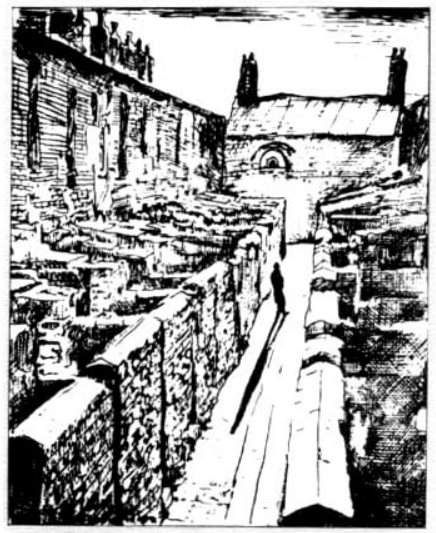

do que 'marionetes, manequins, movidos pela mecânica dos robôs'. A suspeita de que poderfamos ser artifícios já está presente em Descartes: 'Que vejo desta janela, senão chapéus e capotes, que podem cobrir homens fingidos (feints), que apenas se movem por molas?" ".

Sem Deus, lembra Fayette, a metafísica espiritualista, “o mundo cartesiano seria bem inquietante, desrealizado, sem força e profundidade, ele seria só 'uma fábula' "...(43). Dissimulação, teatro, visível invisibilidade. Estes são temas literários, picturais, mitológicos. Mas, como vimos na carta enviada por Descartes a Balzac, políticos. Na corte, em Paris, este ideal é vivido no cotidiano da luta pelo mando. Clima eterno das cortes, legítimas ou tirânicas, é claro. Quando Dionísio tirano envelheceu, conta Plutarco, os cortesãos o imitavam, dando-se mútuos trambolhões. $O$ encanecido déspota perdia a vista. Os bajuladores fingiam nada ver, mas se olhavam, vigilantes, para enxergar quem não fingia cegueira...

Não só os olhos participam desta liturgia do poder. Tambem os ouvidos, como, por exemplo, a conhecida "orelha espiã", ideada pelo padre Kircher, não por acaso da Companhia de Jesus. No quadro que a ilustra, nota-se "os cortesãos que se saúdam. No primeiro andar do edifício, vemos certos seres sombrios em conciliábulo. As intrigas da corte são apenas mencionadas. $\mathrm{O}$ tirano poderá, segundo Kircher, fazer erigir três 'orelhas espiãs' em seu palácio. Uma das 'orelhas' capta todas as palavras dos cortesãos. A segunda 'orelha' faz os sons repercutirem num compartimento que parece um calabouço e em cujo forro encontram-se algumas caixas de ressonância. Também lá as palavras ecoam em direção de uma estátua. Enfim, à direita, vemos a terceira possibilidade: um labirinto acústico gigantesco faz descer as palavras sobre o busto de uma estátua, onde o próprio tirano ouve as mais recentes notícias"(44). Máquinas, maquinações, mechane: campo semântico da metis grega, que precisamos entender em sua extensão polf́tica.

Consultemos um livro atribuído ao cardeal Mazarino, mas com larga difusão na epoca cartesiana. Trata-se do Breviarium politicorum secundum rubricas mazarinicas (1684). "Cartesiana", aqui, significa bem mais do que a obra escrita pelo próprio filosofo. Não me proponho comentar os sutilíssimos parágrafos do texto. Seguirei apenas a perfeita análise de Giovanni Machia(45). Tese barroca: o homem é apenas aparência, "só os outros podem dar-lhe um rosto, porque através do autoconhecimento e dos outros, numa relação contínua, ele pode agir, e agir sobre os demais".

A Época de Mazarino, muito cartesiana, é tempo de uma "dissimulação, como em pintura foi o século da sombra, como via que encaminha para a luz". Mazarino expõe a extrema mobilidade da relação humana dissimulada, porque "contempla as duas posições contrastantes do político: a que assume face aos senhores, e a que toma, diante dos inferiores (...) trata-se de todo um jogo de espelhos invisíveis, mas cujo alvo precípuo é fazer com que apareça como natural a obra da astúcia, com a visão clara, sem mácula, do que é útil à escalada no plano do poder, e de grande interesse para sua conservação".

Mundo polf́tico: corrompido até as raízes, onde se agita "sem cessar um geniozinho maligno, que não concede paz nem mesmo em sonho, fazendo-nos girar no leito à noite, com medo: a suspeita. Ninguem, nem sequer teu melhor amigo, te dirá se falam mal de ti na sua presença, e nem de que pessoas deves guardar-te". Neste espaço solitário, "não e suficiente a imagem do homem no espelho, olhando-se para se conhecer". $O$ político precisa de um espelho posto de forma inclinada, no alto, dirigido para sua frente, a fim de enxergar o que se passa às suas costas".

Século de dissimulação, e do teatro, sobretudo do ator. Século da Ilusão cómica (Corneille). Político é ator, e não usa apenas certa máscara, pois possui muitas. Hábil na metamorfose, para a sobrevivência. Tocamos aqui num dos pontos centrais da exposição feita por Elias Canetti sobre o poder. Trata-se do poderoso como sobrevivente ${ }^{(46)}$. "A metamorfose, adianta Machia, foi outro tema recorrente no teatro barroco, nos maquinistas, encenadores como Giacomo Torelli, tão querido por Mazarino."

Na luta pela sobrevivência, nas metamorfoses do poder, um dado essencial é o segredo. No livro de Mazarino, ou suposto pertencer-lhe, temos a representação obsessiva do poderoso "no alto da escala social, impenetrável, não visto, nos meandros de seu palácio, no seu cabinet, cheio da çabeça aos pés de segredos que ninguém deve conhecer, e desejando (...) que o mundo dos súditos seja exposto a uma luz perene".

Precisamos, agora, indicar a passagem do sonho à dissimulação. Para isto, discutamos a palavra "fingir", em seus espelhamentos polissêmicos. Fingir pode designar tanto um ato da imaginação poética, quanto uma ação teatral e política. Em Descartes, o ar- 
Gumento do sonho, como dificuldade para discriminar o conhecimento das ilusões, continua no artiff́cio do "gênio malicioso". O filosofo, na moral provisória que estabeleceu para si mesmo, aponta estar perfeitamente cônscio da freqüente oposição entre "ser" e "parecer" na vida civil, sobretudo no campo da fala.

"Busco me regular segundo aqueles com os quais devo viver. Para saber as suas opiniões verdadeiras, deveria atentar mais para o praticado, do que ao dito por eles; não só porque, devido à corrupção dos nossos costumes, há poucas pessoas que desejam dizer tudo o que acreditam, mas também porque muitos, eles próprios, o ignoram; pois a ação do pensamento pela qual acreditamos numa coisa, sendo diferente daquela pela qual conhecemos que acreditamos nela, elas existem, freqüentemente, uma sem a outra" (Discurso do método, Pléiade, p. 141). O fingimento, neste passo, é político.

Já num instante posterior, o ato de fingir é poético e metodológico. Como ao estabelecer as condições negativas para a prova da existência divina: "considerando que todos os pensamentos que temos quando despertos podem nos vir tamberm quando dormimos, sem que nenhum deles seja verdadeiro, resolvi fingir (feindre) que todas as coisas que penetraram em meu espírito não eram mais verdadeiras do que as ilusōes de meus sonhos" (idem, IV parte, p. 147). O fingimento possui limites: "examinando atentamente o que eu era, e 'vendo' que eu podia 'fingir' que não tinha nenhum corpo (...) mas que eu não podia 'fingir', por isto, que eu não era (...) seguia-se muito evidentemente e muito certamente que eu era..." (idem, IV parte, p. 148).

$\mathrm{O}$ "eu" só perde a máscara para si mesmo. Face a tudo que lhe é exterior, ou adventício, ele pode fingir. Nas Meditaçōes, a passagem entre o argumento onírico e a prova da existência do cogito, e do ser divino, dá-se pelo obstáculo, "fingido" por Descartes, do gênio malicioso. "Suporei, portanto, que não há um verdadeiro Deus, soberana fonte de toda verdade, mas certo gênio maligno, não menos astucioso e enganador do que potente, que empregou toda a sua indústria em me enganar (genium aliquem malignum, eundemque summe potentem \& callidum, omnem suam industriam in eo posuisse, ut me falleret). Pensarei que o céu, o ar, a terra, as cores, as figuras, os sons e todas as coisas exteriores 'que vemos' são apenas ilusões e engodos, dos quais ele serve-se para surpreender minha credulidade (ludificationes somniorum, quibus insidias credulitati meae tetendit)".

Uma inspeção em callidus, tal como empregado por Descartes acima, ê reveladora. Comparemos com Cícero: “...versutum et callidum factum Solonis". (O ato retorcido e hábil de Solon). Habilidade política, lógico. Mas tamberm suprema astúcia e dolo: "Callidus atque subdolus". (Sagaz e mesmo velhaco, Plauto). Uma Callida liberalitas E liberalidade astuciosa, interesseira. Callida voti são feitos por quem dissimula, oculta seus desejos. Guardamos este campo, no português. Cálido, segundo nosso Aurélio, significa "sagaz, astuto, fino".

Se não tenho poder para o conhecimento, pelo menos estou em condições para a suspensão de meu júzo, "por isto tomarei todo o cuidado para não receber em minha crença nenhuma falsidade, e prepararei tão bem meu esṕrito contra as astúcias deste grande enganador que, por mais poderoso e astuto que ele seja, jamais poderá impor-se a mim (quantumvis potens, quantumvis callidus, possit imponere, obfirmata mente cavebo)". Luta entre poderes. O gênio maligno possui poder, sobretudo através da dissimulação. Posso cair nas suas astúcias, se não suspender meu jứzo, e não souber ler suas intenções escondidas.

Voltemos ao Tratado das paixóes da alma, ao trecho referente à face e ao olhar. A dissimulação e as paixōes manifestas: tamberm aqui, em Mazarino, temos toda uma semiologia do rosto, tornando legiveis os traços da face, no intento da dominação. Leitor de Della Porta, para quem, na fisiognômica se consegue mostrar, na imagem corporal, o fundo da alma, Mazarino inscreve-se de forma sutil na visibilidade. Tambêm lê Antoine Mizauld, que publica em 1565 o livro sobre um novo invento, "para incontinenti julgar o natural de cada um, só pela inspeção da fronte e de seus lineamentos".

Torquato Acetto, no seu Della dissimulazione onesta (1641) mostra o vício como virtude, "honorável e útil". "Se ela é uma virtude para Acetto, trata-se sobretudo do fato que ela é uma arte da máscara. Ele a define como 'máscara, que o bom dissimulador usa, sem que ninguém perceba'. Logo, máscara mascarada. Melhor ainda, ela e 'um esforço para não mostrar as coisas como elas são, simulando o que não $\epsilon$, dissimulando o que é' (una industria di non far veder le cose come sano. Si simula quello che non è, si dissimula quello che è). A simulação é dada como o positivo, cujo negativo é a dissimulação. Mas constituem, ambas, duas faces de uma virtude idêntica. Logo, uma arte

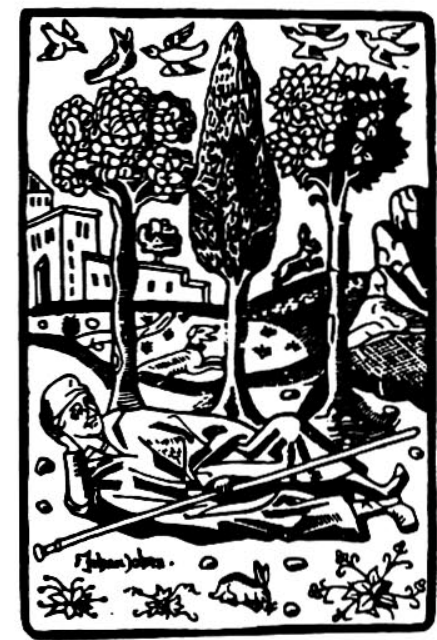

43 'Liminaire 'Perinde ac cadaver' " in L'homme machine, révue philosophique de la France et de l'étranger, n 3 , julho-set./1980.

44 Maneirismo..., Gustav R. Hocke, pp. 196-7.

45 Cf. Breviario del politici, ed. G. Machia. Milano, Rizzoli, 1981.

46 "O poderoso como sobrevivente", in Massa e poder. Ed. Un. Brasilia, 1986.

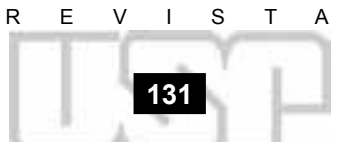


de parecer, de enfeitar, uma 'exibição' muito próxima do ostentatório"(47).

Finalmente, a dissimulação e um corpo instável; como a ostentação poderia escorregar para a vaidade, a dissimulação é contígua à impostura; o homem que se compõe (...) "pode tornar-se hipocrita (o hipócrita é um dos tipos literários inventados pela época)"(48).

Qual a razão de ter eu escolhido o sonho, a dissimulação, o poder, para discutir uma filosofia, a cartesiana, e alguns prismas do barroco? Respondo com Pierre-Alain Cahne: "Argumento central do pirronismo, metáfora privilegiada da condição humana, o sonho barroco" pode ser encontrado em toda a época cartesiana. "Pascal deixa, com efeito, no centro de sua fenomenologia do homem, as descrições barrocas, onde o sonho desempenha um papel essencial".

Filosoficamente, são tambem relevantes as observações de Jacques Derrida sobre o estatuto dos sonhos em Descartes. Mais do que a loucura, a experiência onírica é universal, e radicaliza a dúvida com uma lâmina mais cortante. "Esta referência ao sonho, diz Derrida, constitui, na ordem metódica, a exasperação hiperbólica (barroca diria eu, RR) da hipótese da loucura. Esta afetaria, de forma contingente e parcial, apenas certas regiões da percepção sensível." Mas o adormecido, "face ao problema do conhecimento que interessa Descartes, está mais longe da percepção verdadeira do que o louco. É no caso do sono, e não da extravagância, que a totalidade absoluta das idéias de origem sensivel torna-se suspeita"(49).

$O$ juízo de J. M. Beyssade $\varepsilon$ mais cheio de matizes. "O sonho não $\varepsilon$, na filosofia primeira de Descartes, tão constantemente associado à dúvida da metafísica quanto a experiência dos paralogismos." A garantia divina afasta mediatamente, e não imediatamente, a objeção do sonho. O exemplo onírico é mais especificamente adaptado à crítica do sensível. Ali onde a dúvida sobre a matemática é aprofundada, e distinta da dúvi-

Noła-se, diz Cahné, que łoda a liferałura desta primeira mełade do séc. XVII associa o sonho a conołações negativas - em Descarłes isso é evidente pois trała-se da metófora privilegiada para a vida humana em sua essência agostiniana da "mułabilifas" da sobre o sensível, "o caso do sonho aproxima-se do erro dos sentidos e motiva uma primeira dúvida hiperbólica". Enquanto ilusão, o sonho, entretanto, é mais radical do que todos os erros. As ilusões do sonho formam um universo fechado: "Nenhuma experiência interna ao mundo do sonhador pode corrigi-las. Elas são contestadas em bloco, de fora, em proveito de um universo diferente, que não $e$ o do sonhador". Entretanto, "a objeção do sonho, decisiva contra os conhecimentos sensíveis, é inoperante contra as evidências intelectuais"(50).

Cahné estuda a formação do próprio léxico barroco, mostrando, nele, a palavra songe sistematicamente associada à "imagem", esta última pensada num remanejamento moderno do "ídolo" platônico. Exemplo: o sintagma recorrente, "as imagens de um sonho", contém uma caracterização hiperbólica, pur encaixe, de uma aparência da aparência. Como em Tristan l'Hermite:

\section{L'ombre de cette fleur vermeille \\ Et celle de ces joncs pendants \\ Paraissent être là-dedans \\ Les songes de l'eau qui sommeille}

Nota-se, diz Cahne, que toda a literatura desta primeira metade do século XVII associa o sonho a conotações negativas - em Descartes isto é evidente - pois trata-se de metáfora privilegiada para a vida humana em sua essência agostiniana da mutabilitas. Mas é a vida toda, então - e isto também é verdadeiro em Descartes - que, sem Deus, torna-se negativa quando vista em si mesma. "Pois a vida $\varepsilon$ um sonho um pouco menos inconsistente", fala o fragmento 803 de Pascal, nos Pensamentos. Ou, no poeta Des Barreaux, conhecido por Pascal:

\section{Le dirai-je, Mortels, qu'est-ce que cette vie? \\ $C$ 'est un songe qui dure un peu plus qu'une nuit.}

Segundo Cahne, que sigo integralmente, em letra e espírito aqui, apenas parafraseando suas argumentações, a temática barroca não cessa de repetir a total ausência de dife- 
rença entre vigflia e sonho. Este, não é mais comunicação com os deuses (Deus se esconde, em Pascal), nem visão do futuro. Ele é o conjunto de todas as marcas da vida:

\section{Est-il rien de plus vain qu'un songe mensonger \\ Un songe passager, vagabond et muable? \\ La vie est toutefois au songe comparable, \\ Au songe vagabond, muable e passager ${ }^{(51)}$.}

Sigamos a análise desse quarteto, feita por Cahne: tudo nele se organiza ao redor da mutabilidade. $\mathrm{Na}$ ordem das palavras (mensonge), das aparências sensíveis (muable), do tempo (passager), ou da existência ordinária (vagabond). O sonho é comparante privilegiado da vida, e a retomada, inversa e em quiasma, dos elementos que caracterizam o poema, implica um jogo especular e de inversões onde não é mais o sonho o espelho da vida, mas a vida é imagem do sonho.

Pascal usa os antônimos para definir a vida-sonho, o sonho-vida:

Qui sait si cette autre moitié de la vie où nous pensons veiller n'est pas un autre sommeil un peu different du premier?

A filosofia cartesiana fornece firmemente as chaves terminologicas de Pascal: certeza, segurança. Mas é preciso a fé para romper o balanço entre vigília e sonho. Sonho, para Descartes, pelo menos na "Segunda meditação", ê um movimento apaixonado. Nele, nunca somos livres ${ }^{(52)}$.

\section{CONCLUSĀO (INCONCLUSA...)}

Discutimos apenas uma imagem, a do sonho, ao redor da visibilidade e da vida polftica. Tocamos, na ótica, a prática da dissimulação, e pontos conexos. Isto nos fornece uma idéia, longínqua, da complexidade convencionalmente chamada "barroco". Ficamos, alêm disto, só na filosofia cartesiana, deixando as demais na sombra. Muito teríamos a dizer sobre Hobbes, ou Gassendi, neste campo. Seriam necessárias mil e uma noites - mais o encanto da narradora - para tocar amplamente no tema proposto. E falamos apenas da França. Poderfamos lembrar a Alemanha, com Andreas Gryphius, por exemplo:

\section{Was sind wir menschen doch? ein wohnhaus grimmer schmertzen. (...) \\ Gleich wie ein eitell traum leicht aus der acht hinfält \\ (...) wir vergehn gleich als ein rauch von winden ${ }^{(53)}$.}

Ou então:

\author{
Was wir für ewig schätzen \\ Wirdt als ein leicheter traum vergehn. \\ (...) \\ Was ist des Menschen leben \\ Der immer umb mus schweben \\ Als eine phantasie der zeit ${ }^{(5)}$.
}

Ficamos, por outro lado, apenas nos arredores de uma teoria imagética da escrita, tal como se apresenta no barroco. Não a desenvolvemos ${ }^{(55)}$. Os materiais que apresentamos, podem "indicar" vias para o recolhimento do pensar cartesiano, fora das informes ordens "das razões", onde as figuras estilísticas desaparecem, como um sonho. Ou pesadelo.

A temática onírica, na própria especulação filosófica moderna, pós-cartesiana, ๔ ampla, diff́cil, importante. No século XVIII, lembremos apenas $O$ sonho de d'Alembert (Diderot) e os Devaneios de um caminhante solitário (Rousseau). $O$ livro dos sonhos, de Swedenborg, e sua crítica irreverente nos Sonhos de um visionário, explicados pelos sonhos da Metafisica, de Kant. Isto, para não comentar também o que se deu no século XIX, e no XX, com a pletora dos românticos, simbolistas, e tantos outros veios mais da

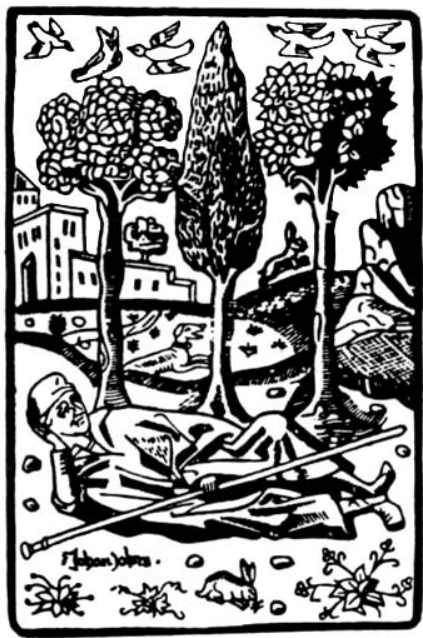

47 "Le Baroque", J. Rousset, in Histoire des littératures. Pléiade, v. 2, pp. 101-2.

48 Idem, ibidem, p. 102.

49 Cf. L'écriture et la difference. Paris, Seull, 1967, p. 51 e segs.

50 La philosophie premiere..., J. M. Beyssade, pp. 84-5.

51 Chassignet, in Anthologie de la poo sie baroque française. Paris, Armand Colin, 1961, p. 71. Citado por Cahné, P. A. "Reve et songe. Lexique et idéologie". Révue des Sciences Humaines, $n^{2} 211$, 1988-3, p. 195.

52 P. A. Cahne, op. cit., p. 198.

53 Menschliches Elende: na espera de um poeta tradutor: "Que somos nos, os humanos, pois? Uma estalagem alucinante de sotrimentos $($ (...) Como um sonho cal no esquecimento/(...) Sumimos qual fumaça nos ventos".

54 Vanitas! Vanitatum Vanitas! Com as mesmas desculpas: "O que consideramos eterno/ Torna-se um sonho que some $(. ..) \bigcirc$ que $e$ a vida humana Que sempre deve flutuar? Uma fantasia do tempo".

$55 \mathrm{Cf}$. o belo estudo de Haroldo de Campos, Deus e o diabo no Fausto de Goethe. SP, Perspectiva, 1981. Sobremodo, à p. 132 e segs.

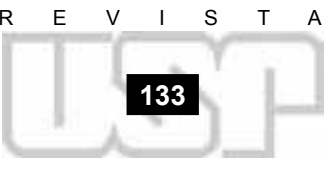


cultura, que evoluíram ao redor do encanto, do sonho, do sono. Pouco teríamos a dizer, do que o já formulado por Albert Beguin, no clássico L'Ame romantique et le rêve (1939).

\section{MUNDUS EST FABULA}

O problema da simulação, e a dissimulação, em Descartes, passa por dois registros, como vimos: o poético e o político. Ambos "fingem" seu mundo. O filósofo transforma este fingimento em método. No quadro de J. B. Weenix, Descartes segura um livro aberto em que se pode ler a frase acima. Pierre-Alain Cahné a comenta, aproximando-a do capítulo VII de $O$ mundo. Naquele texto, Descartes afirma que não fará demonstrações completas sobre todos os pontos requeridos pela marcha científica. Só dará, diz ele, os meios para sua descoberta, "aos que tiverem o trabalho de procurar". Acrescenta: "Para fazer um quadro que vos agrade, é preciso que eu empregue sombra e cores claras também. Tanto me contentaria prosseguir a descrição que iniciei, como não tendo outro desejo senão o de vos narrar uma fábula".

Por esta ficção, Descartes imagina uma gênese, diz Cahné, onde o ato criador divino se reduziria à criação da matéria, a qual ele teria dado "num caos mais confuso e embrulhado que os poetas poderiam descrever". Este impulso teria definido todos os movimentos desta matéria, cujas formas são infinitas. O filósofo propõe-se imaginar como "as partes deste caos separam-se por si mesmas, e dispõem-se em tão boa ordem que terão a forma de um mundo muito perfeito e no qual veremos não só a luz, mas todas as demais coisas...".

Ele opõe este mundo "fingido" a este "mundo verdadeiro", esperando desvelar em seu mundo imaginado a própria realidade. De modo geral, termina Cahné, Descartes avança sempre sua f́́sica, $n^{\prime}$ en déplaise Frances Yates, de modo imaginário. $\mathrm{O}$ mundo é fábula, é a palavra do homem que o faz ser. Luz e sombras o definem, como diz $O$ mundo. $\mathrm{O}$ quadro, para agradar, precisa de ambos os lados. A clara vigflia se espelha, invertida, no seu oposto, a obscura dúvida, o sonho. As duas compõem a totalidade visual e poética, trocaica, apanhada no cogito. Razão sem sonhos é algo tão sem fundamento quanto a luz sem trevas.

Este desdobramento barroco não é considerado nas histórias das filosofias taxinômicas, filhas de Aristóteles. E nunca é demais repetir com Elias Canetti: o modo de pensar aristotélico "E arte de tudo repartir em compartimentos". O Estagirita ê "um pensador desprovido de sonho (ao contrário de Platão). Ele exibe amplamente seu desprezo dos mitos, e quando os poetas não lhe são úteis, não os aprecia"(56).

Quanto a nós, talvez valha o desalentado poema de Edgar Allan Poe: "Is all that we see or seem/But a dream within a dream?"(57).

\section{BIBLIOGRAFIA (incompleta)}

BALTRUŠ AITIS, J. Anamorphoses. Paris, Flammarion, 1984.

- .Le miroir. Elamyon, Seuil, 1978.

BEYSS ADE, J. - M. La philosophie première de Descartes. Paris, Flammarion, 1979.

CAHNÉ, P. A. "Rêve et songe. Lexique et idéologie", in Révue des Sciences Humaines, 211, 1988-3, p. 193 e segs. - Un autre Descartes. Le philosophe et son langage. Paris, Vrin, 1980.

CANETTI, Elias. Massa e poder. Brasflia, Ed. Universidade de Brasflia, 1986.

. Le territoire de l homme. Paris, Albin Michel, 1978.

DADOGNET, F. Philosophie de limage. Paris, Vrin, 1984.

DERRIDA, J. L'écriture et la difference. Paris, Seuil, 1967.

DESCARTES, R. Oeuvres et lettres. NRF, Gallimard, La Pleiade, 1953.

FORESTIER, G. "Le rêve littéraire du barroque au classicisme: réflexes typologiques et enjeux esthétiques", in Revue des Sciences Humaines, $211,1988-3$, p. 213 e segs.

LEDUC-FA YETTE. "Liminaire "Perinde ac cadaver" ", in Révue Philosophique de la France et de lÉtranger, 3, juillet-septembre/1980.

MAZARINO (cardeal). Breviario dei Politici, ed. G. Machia. Milano, Rizzoli, 1981.

SAINTE-BEUVE. Port-Royal. Ed. La Pléiade (v. I) 1953.

SANTIAGO SEBASTIAN. Contrarreforma y Barroco. Madrid, Alianza, 1981.

56 Le territoire de l'homme. Paris, Albin Michel, 1978, p. 50.

57 "É tudo o que vemos ou vimos/Apenas um sonho num sonho? (com as escusas necessárias).
SIMON, G. "Descartes, le rêve et la philosophie", in Révue des Sciences Humaines, 211, 1988-3, p. 133 e segs.

VÁRIOS. Folie et Deraison d la Renaissance. Coloquio Internacional (1973). Ed. Universidade de Bruxelas, 1976

YATES, F. The Rasacrucian Enlightenment. Bouldes, Shambala, 1972.

- . L'art de la mémoire. Paris, Gallimard, 1975. 